\title{
sciendo
}

CIVIL AND ENVIRONMENTAL ENGINEERING REPORTS

E-ISSN 2450-8594

CEER 2019; 29 (2): 001-012

DOI: 10.2478/ceer-2019-0011

Original Research Article

\section{THE ROLE AND EFFECTIVENESS OF THE MBT INSTALLATION IN POLAND BASED ON SELECTED EXAMPLES}

\author{
Marta WIŚNIEWSKA ${ }^{1}$, Krystyna LELICIŃSKA-SERAFIN ${ }^{1}$ \\ Warsaw University of Technology, Warsaw, Poland
}

\begin{abstract}
The paper presents examples of installations for the mechanical and biological treatment of municipal waste in Poland. Each of the presented installations is defined as a regional municipal waste treatment installation (RIPOK). Their technological solutions and work efficiency have been compared in this study. In addition, the loss of waste mass as a result of processes occurring in the biological part of individual installations was calculated in the research. The paper refers to the National Waste Management Plan (KPGO 2022) regarding the circular economy. As intended by the circular economy, MBP installations will be transformed into installations that will treat selectively collected municipal waste and become Regional Recycling Centers (RCR).
\end{abstract}

Keywords: mechanical and biological treatment of municipal waste, municipal waste, mass loss

\section{GENERAL RULES}

Recent years have seen major changes taking place in waste management. Awareness has increased in the sphere of environmental care and protection of nature's resources.

The technology of mechanical and biological treatment of municipal waste in its current form was first used in Germany and Austria in the 1990s [4], [10]. Today,

\footnotetext{
${ }^{1}$ Corresponding author: Warsaw University of Technology, Faculty of Building Services, Hydro and Environmental Engineering, Nowowiejska st 20, 00-653 Warsaw, e-mail: marta.wisniewska.89@wp.pl, tel.+48222345407
} 
MBT installations are far more developed. Sorting plants, which belong to the mechanical part of the installation, allow the separation of raw materials (for recovery). The biological treatment of waste enables its stabilization and reduction in quantities (and in the case of biodegradable waste collected selectively - the production of compost, which is not waste). According to KPGO 2022 [11], MBT installations are to ultimately change their previous purpose and serve as installations for cleaning waste collected selectively (the mechanical part). If the existing waste collection systems are changed and selective collection is not a choice but a necessity, it may be assumed that the MBT installations will change their name to Regional Recycling Centers (RCR) [5].

The work presents selected MBT installations, which are also regional municipal waste treatment installations (RIPOK). These installations are located in the following villages: Poświętne near Płońsk, Kobierniki near Płock and Stary Las near Starogard Gdański. The focus was primarily on the level of waste mass loss during the processes.

\section{METHODOLOGY}

The research and analysis were carried out on the basis of documentation provided by selected MBP installations. Data from three RIPOK installations on waste treated and generated there were used. They were provided by individual plants for the purpose of this work. They constituted the basis for carrying out research that allowed the assessment of effectiveness and verification of problems. On the basis of the above-mentioned data, the balance of waste mass in the analyzed installations was presented, and then on this basis - the loss of waste mass during processing. The level of waste mass reduction following the mechanical part was determined as well as mass loss as a result of aerobic stabilization. The analyzed data were recorded in 2016.

\section{INSTALLATIONS SUBJECTED TO ANALYSIS}

This study covers the analysis of three MBT installations, whose technological processes differ to some extent in terms of both the mechanical and biological parts. This has an impact on the efficiency of the separation of raw material waste, as well as on the biodegradable waste mass reduction.

\subsection{Waste management plant in Poświętne}

The plant located in Poświętne near Płońsk operates based on an integrated permit issued on 27 April 2016. Depending on the needs, the installation can be used for: mechanical and biological treatment of mixed municipal waste, mechanical 
treatment of waste from selective collection, biological treatment of green waste, as well as other biowaste of municipal origin.

The key components of the mechanical part are the preparation and loading system (bag tearer, conveyors), six sorting cabinets, a three-fraction drum sieve, two iron metal separators, three optical-pneumatic separators, an automatic baling press with a bottle perforator, an automatic container loading station, a green waste chopper, and process control and monitoring system.

The biological part of the discussed installation takes place in the reactors separately for the subsieve fraction as well as green waste and other biowaste of municipal origin - using the BIODEGMA system. The first stage is run for at least two weeks in both cases. The second phase is the maturing stage, which is carried out on a square dedicated for this purpose (in an open area). The stabilized product matures on the square for at least 6 weeks; in the case of compost, the period is shorter (minimum 3 weeks) [12].

On 1 May 2016, the plant began to operate based on the integrated permit [6] and mechanical processing has since then been carried out in two variants - in relation to mixed municipal waste and to raw waste (from selective collection). Biological processing was from then on run separately for the $0-80 \mathrm{~mm}$ fraction and for biodegradable waste collected selectively. Table 1 presents the general waste balance for 2016.

Tab. 1. The balance of waste at Waste Management Plant in Poświętne (data for 2016 year) [3]

\begin{tabular}{|c|c|c|c|c|}
\hline $\begin{array}{l}\text { The type of } \\
\text { processing }\end{array}$ & \multicolumn{2}{|c|}{ Waste treated at the plant } & \multicolumn{2}{|c|}{ Waste generated at the plant } \\
\hline \multirow{4}{*}{$\begin{array}{l}\text { Mechanical } \\
\text { treatment } \\
\text { (sorting) } \\
\text { R12 }\end{array}$} & $\begin{array}{c}\text { The type and code } \\
\text { of waste }\end{array}$ & $\begin{array}{c}\text { The mass } \\
\text { of waste } \\
{[\mathrm{Mg}]}\end{array}$ & $\begin{array}{c}\text { The type and code } \\
\text { of waste }\end{array}$ & $\begin{array}{c}\text { The mass } \\
\text { of waste } \\
{[\mathrm{Mg}]}\end{array}$ \\
\hline & $\begin{array}{l}\text { Unsorted } \\
\text { municipal waste } \\
(200301)\end{array}$ & 57999.2 & $\begin{array}{l}\text { Other waste from } \\
\text { mechanical } \\
\text { processing }(0 \div 80 \\
\text { mm fraction, } \\
\text { subsieve) (19 } 12 \\
12) \\
\end{array}$ & $29,960.6$ \\
\hline & \multirow[t]{2}{*}{$\begin{array}{l}\text { Other selectively } \\
\text { collected waste }\end{array}$} & \multirow[t]{2}{*}{$2,573.4$} & $\begin{array}{l}\text { Other waste from } \\
\text { mechanical } \\
\text { treatment (over- } \\
\text { sieve fraction, } \\
\text { ballast) (19 12 12) }\end{array}$ & $11,979.6$ \\
\hline & & & $\begin{array}{c}\text { Separate waste } \\
\text { fractions destined } \\
\text { for recovery }\end{array}$ & $12,635.4$ \\
\hline TOTAL & \multicolumn{2}{|c|}{$60,572.6$} & \multicolumn{2}{|l|}{$54,575.6$} \\
\hline
\end{tabular}




\begin{tabular}{|c|c|c|c|c|}
\hline \multirow{3}{*}{$\begin{array}{l}\text { Biological } \\
\text { treatment } \\
\text { (composting) } \\
\text { R3 }\end{array}$} & $\begin{array}{l}\text { Other waste from } \\
\text { mechanical } \\
\text { processing }(0 \div 80 \\
\text { mm fraction) }(19 \\
1212) \\
\end{array}$ & $10,967.1$ & \multirow[t]{2}{*}{$\begin{array}{l}\text { Other waste not } \\
\text { listed (19 } 0599)\end{array}$} & \multirow[t]{2}{*}{$5,864.4$} \\
\hline & waste (20 02 01) & 77.1 & & \\
\hline & $\begin{array}{c}\text { Biodegradable } \\
\text { waste }(200201)\end{array}$ & 460.8 & $\begin{array}{l}\text { Compost not } \\
\text { meeting the } \\
\text { requirements (19 } 05 \\
03)\end{array}$ & 88.3 \\
\hline $\begin{array}{l}\text { Biological } \\
\text { treatment } \\
\text { D8 }\end{array}$ & $\begin{array}{l}\text { Other wastes from } \\
\text { mechanical } \\
\text { processing }(0 \div 80 \\
\text { mm fraction) }(19 \\
1212)\end{array}$ & $18,993.5$ & $\begin{array}{l}\text { Other wastes not } \\
\text { listed (19 05 99) }\end{array}$ & $11,003.5$ \\
\hline TOTAL & \multicolumn{2}{|l|}{$30,498.5$} & \multicolumn{2}{|l|}{$16,956.2$} \\
\hline
\end{tabular}

As a result of waste treatment in the mechanical part of the installation, a mass loss of $9.9 \%$ was observed. A significantly larger loss of waste mass (reaching over $40 \%$ ) was, of course, obtained as a result of biological processing. The product of the biological processing of the $0-80 \mathrm{~mm}$ fraction and other biodegradable waste was waste marked with code 190599 (other unlisted waste), with part of the waste mass originating from the recovery process (R3) and part from the disposal process (D8). From May 2016, biodegradable waste was processed separately (as a result of obtaining an integrated permit), while the product of this process was compost not meeting the requirements of code 1905 03. Although the process involved biodegradable waste collected selectively, no organic fertilizer was obtained. The recorded loss of mass after the composting process of biodegradable waste stood at a very high level $-80.8 \%$. This result raises doubts, especially considering the 5-week duration of this process.

\subsection{Municipal Waste Utilization Plant in the village of Kobierniki}

This plant is located in the village of Kobierniki near Płock. On July 21, 2016, the installation being part of the Plant obtained an integrated permit for the operation of installations for recovery or connection of waste recovery and disposal processes with a processing capacity of $75 \mathrm{Mg}$ per day. The installation can run in several variants - for the purpose of: mechanical and biological processing of mixed municipal waste, mechanical treatment of waste from selective collection, biological processing of green waste, and other biowaste of municipal origin or biological treatment of non-municipal biodegradable waste.

The installation in the mechanical part is equipped with a waste preparation and loading system. The waste bags are torn manually on a sorting belt, where a 
preliminary, manual segregation follows. The following are also used: a doublesided drum sieve, iron metal separators, a sorting cabin, a channel press and a final shredder.

Biological treatment takes place in reactors - reinforced concrete containers. The entire process includes three stages. In the first one, the waste is placed in reactors, formed into piles and covered with the Gore Cover semi-permeable membrane. In the case of the $0 \div 80 \mathrm{~mm}$ fraction the first phase (intensive stabilization) takes about five weeks. The second phase (maturing) takes place once the stabilized material is transferred to the next container, lasting ca. $2 \div 3$ weeks and also occurring under the membrane. The third phase is also the maturing stage, but it is carried out in heaps laid out in an open area. The total duration of biological treatment of the undersieve fraction in the Plant lasts approx. 10-12 weeks. The biological processing of biodegradable waste collected selectively occurs in a similar way [7]. Table 2 presents the general waste balance for 2016.

Tab. 2. The balance of waste at Waste Management Plant in Poświętne (data for 2016) [3]

\begin{tabular}{|c|c|c|c|c|}
\hline \multirow[b]{2}{*}{$\begin{array}{l}\text { The type of } \\
\text { processing }\end{array}$} & \multicolumn{2}{|c|}{ Waste treated at the plant } & \multicolumn{2}{|c|}{ Waste generated at the plant } \\
\hline & $\begin{array}{l}\text { The type and } \\
\text { code of waste }\end{array}$ & $\begin{array}{c}\text { The mass } \\
\text { of waste } \\
{[\mathrm{Mg}]}\end{array}$ & $\begin{array}{c}\text { The type and code } \\
\text { of waste }\end{array}$ & $\begin{array}{c}\text { The mass } \\
\text { of waste } \\
{[\mathrm{Mg}]}\end{array}$ \\
\hline \multirow{2}{*}{$\begin{array}{c}\text { Mechanical } \\
\text { treatment } \\
\text { (sorting) } \\
\text { D13 - waste } \\
\text { marked with the } \\
\text { code } 200301 \\
\text { R12 - other } \\
\text { waste }\end{array}$} & $\begin{array}{c}\text { Unsorted } \\
\text { municipal waste } \\
(200301)\end{array}$ & $49,434.4$ & $\begin{array}{c}\text { Material waste } \\
\text { divided into } \\
\text { fractions and spent } \\
\text { devices containing } \\
\text { hazardous } \\
\text { substances and } \\
\text { other spent } \\
\text { equipment. }\end{array}$ & $2,727.0$ \\
\hline & $\begin{array}{c}\text { Other } \\
\text { selectively } \\
\text { collected waste }\end{array}$ & $5,994.9$ & $\begin{array}{c}\text { Other waste from } \\
\text { mechanical } \\
\text { treatment } \\
(191212)\end{array}$ & $36,643.3$ \\
\hline TOTAL & 55,429 & & $48,609.8$ & \\
\hline
\end{tabular}




\begin{tabular}{|c|c|c|c|c|}
\hline \multirow{5}{*}{$\begin{array}{c}\begin{array}{c}\text { Biological } \\
\text { treatment } \\
\text { (composting) }\end{array} \\
\text { D8 - waste } \\
\text { marked with the } \\
\text { code } 191212 \\
\text { R3 - other waste }\end{array}$} & $\begin{array}{c}\text { Sawdust, } \\
\text { shavings, wood } \\
\text { cuttings, } \\
\text { particle boards } \\
\text { and veneered } \\
\text { panels other } \\
\text { than those in } 03 \\
0104(0301 \\
05)\end{array}$ & 0.2 & $\begin{array}{l}\text { Compost not } \\
\text { meeting the } \\
\text { requirements } \\
\text { (19 05 03) }\end{array}$ & $7,906.1$ \\
\hline & $\begin{array}{c}\text { screenings (19 } \\
0801)\end{array}$ & 4.3 & \multirow{4}{*}{$\begin{array}{l}\text { Other waste not } \\
\text { listed (19 } 0599)\end{array}$} & \multirow{4}{*}{$2,467.2$} \\
\hline & $\begin{array}{l}\text { Biodegradable } \\
\text { kitchen waste } \\
\left(\begin{array}{l}200108) \\
\end{array}\right.\end{array}$ & 79.0 & & \\
\hline & $\begin{array}{c}\text { Biodegradable } \\
\text { waste }(2002 \\
01)\end{array}$ & $2,944.2$ & & \\
\hline & $\begin{array}{c}\text { Other waste } \\
\text { from } \\
\text { mechanical } \\
\text { treatment (19 } 12 \\
\text { 12) }(0 \div 80 \mathrm{~mm} \\
\text { sieve fraction })\end{array}$ & $9,239.5$ & & \\
\hline TOTAL & \multicolumn{2}{|c|}{$12,267.2$} & \multicolumn{2}{|c|}{$10,373.3$} \\
\hline
\end{tabular}

During the mechanical treatment of waste, a mass loss of $12.3 \%$ was recorded, which - similarly to the plant in Poświętne - could have been caused by the discharge of water and other liquids as a result of tearing bags and shredding waste. Biological processing generated waste in the form of: compost not meeting the requirements $(76.2 \%)$ and other unlisted waste $(23.8 \%)$. The mass loss occurring due to these processes amounted to $15.4 \%(1894.0 \mathrm{Mg})$.

\subsection{Municipal Waste Utilization Plant in Stary Las}

Waste treatment in the Plant is based on administrative decisions, including an integrated permit, which was obtained for the first time for the Plant in June 2012. The permit was repeatedly changed over the years 2012-2014 as a result of, among others, the Plant's expansion resulting from the addition of an installation for the biological treatment of waste with the options of biostabilization, biodrying and composting.

The processing of waste delivered to the plant through the recovery process is carried out mainly using: a sorting plant, an alternative fuel production line, a station for processing large-size waste and shredding rubble, as well as 
installations for biological processing, alongside a Kneer container composting system.

In the mechanical part, the sorting is carried out manually and mechanically (sorting cabin, separators: electromagnetic, optical and ballistic).

The biological processing installation comprises three processes, defined at the Plant as: biostabilization, biodrying and composting. They occur in the same place but interchangeably, depending on the algorithm set in the computer system. Waste subjected to biostabilization is poured into piles in containers, and then covered with fabric from a semi-permeable membrane. The intensive stabilization phase lasts 14 days. The second phase of the process (maturation) - retention in a closed reactor - takes 14 days. The outcome of biostabilization is a stabilized product (19 0599 - other unlisted waste) and compost not meeting the requirements (19 0503$)$ [9].

The composting process follows similarly to the biostabilization process. Then, after sieving on a mobile sieve with a mesh size equal to $20 \mathrm{~mm}$, the following are separated: the over-sieve fraction (code 190501 ), which is again directed to the composting process and the undersieve fraction (code 1905 03), which is stored and sent to external recipients or subjected to processing in installations on the Plant's premises.

Waste marked with code 200301 and 1912 12is subjected to biodrying. The biodrying process proceeds in the same reactors, but it lasts approx. 9 days. Its product is waste with code 190501 (non-composted fractions of municipal waste and the like), which are then subjected to further mechanical treatment in the sorting plant in the R12 process. However, waste that arises as a result of biodrying may be classified under code 191210 (combustible waste) in cases where the input material is waste with code 191212.

The Plant also has a Kneer container composting system for processing, among others: stabilized municipal sewage sludge (19 08 05), biodegradable kitchen waste $(200108)$ and biodegradable waste $(200201)$. The first phase - intensive composting - is carried out in the Kneer system installation and lasts approx. 14 days (up to 21 days). The second phase is the maturation of biomass and takes place in the open air (the material is poured on a roofed plate into a pile and passed through a self-propelled gantry turner). The material matures in a heap for approx. 6-8 weeks $[8,9]$.

Table 3 presents the balance of mass of waste processed and generated as a result of these processes for 2016 . 
Tab. 3. The balance of waste at Waste Management Plant in Stary Las for selected installations (data for 2016 [2])

\begin{tabular}{|c|c|c|c|c|}
\hline \multirow[b]{2}{*}{$\begin{array}{l}\text { The type of } \\
\text { processing }\end{array}$} & \multicolumn{2}{|c|}{ Waste treated at the plant } & \multicolumn{2}{|c|}{ Waste generated at the plant } \\
\hline & $\begin{array}{c}\text { The type and code } \\
\text { of waste }\end{array}$ & $\begin{array}{l}\text { The mass } \\
\text { of waste } \\
{[\mathrm{Mg}]}\end{array}$ & $\begin{array}{c}\text { The type and code } \\
\text { of waste }\end{array}$ & $\begin{array}{c}\text { The mass } \\
\text { of waste } \\
{[\mathrm{Mg}]}\end{array}$ \\
\hline \multirow{3}{*}{$\begin{array}{c}\text { Mechanical } \\
\text { treatment } \\
\text { (sorting) } \\
\text { R12 }\end{array}$} & $\begin{array}{c}\text { Unsorted } \\
\text { municipal waste } \\
(200301)\end{array}$ & $43,517.1$ & $\begin{array}{l}\text { Raw material waste } \\
\text { divided into } \\
\text { fractions of spent } \\
\text { equipment }\end{array}$ & $5,388.6$ \\
\hline & $\begin{array}{l}\text { Non-composted } \\
\text { fractions of } \\
\text { municipal and } \\
\text { similar waste (19 } \\
0501)\end{array}$ & $1,398.8$ & \multirow{2}{*}{$\begin{array}{l}\text { Other waste from } \\
\text { mechanical } \\
\text { treatment, other } \\
\text { than that listed in } \\
191211\left(\begin{array}{ll}19 & 12\end{array}\right)\end{array}$} & \multirow[t]{2}{*}{$50,237.2$} \\
\hline & $\begin{array}{l}\text { Other selectively } \\
\text { collected waste }\end{array}$ & $10,709.9$ & & \\
\hline TOTAL & \multicolumn{2}{|c|}{$55,625.8$} & \multicolumn{2}{|l|}{$55,625.8$} \\
\hline \multirow{2}{*}{$\begin{array}{c}\text { Biological } \\
\text { treatment } \\
\text { (biostabilizatio } \\
\text { n) } \\
\text { D8 }\end{array}$} & \multirow{2}{*}{$\begin{array}{l}\text { Other waste from } \\
\text { mechanical } \\
\text { treatment, other } \\
\text { than that listed in } \\
191211(1912 \\
12)\end{array}$} & \multirow[t]{2}{*}{$30,321.0$} & $\begin{array}{l}\text { Compost not } \\
\text { meeting the } \\
\text { requirements (19 } 05 \\
03)\end{array}$ & $15,975.1$ \\
\hline & & & $\begin{array}{l}\text { Other waste not } \\
\text { listed (19 } 05 \text { 99) }\end{array}$ & $9,072.9$ \\
\hline TOTAL & \multicolumn{2}{|l|}{$\begin{array}{r}30,321.0 \\
\end{array}$} & \multicolumn{2}{|l|}{$25,048.0$} \\
\hline $\begin{array}{c}\text { Biological } \\
\text { treatment } \\
\text { (biodrying) } \\
\text { R12 } \\
\end{array}$ & $\begin{array}{c}\text { Unsorted } \\
\text { municipal waste } \\
(200301)\end{array}$ & 162.4 & $\begin{array}{l}\text { Non-composted } \\
\text { fractions of } \\
\text { municipal and } \\
\text { similar waste (19 } \\
0501)\end{array}$ & $1,398.8$ \\
\hline TOTAL & \multicolumn{2}{|l|}{162.4} & \multicolumn{2}{|l|}{$1,398.8$} \\
\hline \multirow{3}{*}{$\begin{array}{c}\text { Biological } \\
\text { treatment } \\
\text { (composting) } \\
\text { R3 }\end{array}$} & $\begin{array}{c}\text { Materials } \\
\text { unsuitable for } \\
\text { consumption or } \\
\text { processing (02 } 02 \\
03)\end{array}$ & 48.9 & & \multirow{3}{*}{$6,248.8$} \\
\hline & $\begin{array}{c}\text { Materials } \\
\text { unsuitable for } \\
\text { consumption and } \\
\text { processing (02 } 06 \\
01)\end{array}$ & 0.2 & $\begin{array}{l}\text { Compost not } \\
\text { meeting the } \\
\text { requirements (19 } 05 \\
\text { 03) }\end{array}$ & \\
\hline & $\begin{array}{c}\text { Sawdust, } \\
\text { shavings, cuttings, } \\
\text { wood, particle }\end{array}$ & 94.4 & & \\
\hline
\end{tabular}


THE ROLE AND EFFECTIVENESS OF THE MBT INSTALLATION IN POLAND 9 BASED ON SELECTED EXAMPLES

\begin{tabular}{|c|c|c|c|c|}
\hline & $\begin{array}{c}\text { boards and } \\
\text { veneered panels } \\
\text { other than those } \\
\text { listed in } 030104 \\
\left(\begin{array}{lll}03 & 0105\end{array}\right)\end{array}$ & & & \\
\hline & $\begin{array}{l}\text { Food products that } \\
\text { are past their } \\
\text { expiry date or } \\
\text { unfit for } \\
\text { consumption } \\
(160380)\end{array}$ & 29.3 & \multirow{5}{*}{$\begin{array}{l}\text { Non-composted } \\
\text { fractions of } \\
\text { municipal and } \\
\text { similar waste } \\
(190501)\end{array}$} & \multirow{5}{*}{$2,214.3$} \\
\hline & $\begin{array}{c}\text { Waste from } \\
\text { sewage treatment } \\
\text { plants }\end{array}$ & $1,841.4$ & & \\
\hline & $\begin{array}{l}\text { Non-composted } \\
\text { fractions of } \\
\text { municipal and } \\
\text { similar waste } \\
\text { (19 05 01) }\end{array}$ & $2,214.3$ & & \\
\hline & $\begin{array}{c}\text { Wood (19 } 1207 \\
\text { and } 200138)\end{array}$ & 590.5 & & \\
\hline & 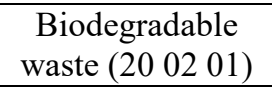 & $8,391.1$ & & \\
\hline TOTAL & \multicolumn{2}{|l|}{$\begin{array}{r}13,209.8 \\
\end{array}$} & \multicolumn{2}{|c|}{$8,463.1$} \\
\hline \multirow{4}{*}{$\begin{array}{c}\text { Biological } \\
\text { treatment } \\
\text { (Kneer } \\
\text { container } \\
\text { composting ) } \\
\text { R3 }\end{array}$} & $\begin{array}{l}\text { Raw materials and } \\
\text { products } \\
\text { unsuitable for } \\
\text { consumption or } \\
\text { processing } \\
(020203)\end{array}$ & 28.8 & $\begin{array}{l}\text { Compost not } \\
\text { meeting the } \\
\text { requirements } \\
(190503)\end{array}$ & $2,056.7$ \\
\hline & $\begin{array}{c}\text { Stabilized } \\
\text { municipal sewage } \\
\text { sludge (19 08 05) }\end{array}$ & 30.0 & \multirow{3}{*}{$\begin{array}{l}\text { Other waste not } \\
\text { listed (19 05 99) }\end{array}$} & \multirow{3}{*}{580.4} \\
\hline & Wood (19 12 07) & 7.0 & & \\
\hline & $\begin{array}{l}\text { Other waste from } \\
\text { mechanical } \\
\text { treatment } \\
(191212)\end{array}$ & $5,762.3$ & & \\
\hline TOTAL & \multicolumn{2}{|c|}{$5,828.3$} & \multicolumn{2}{|c|}{$2,637.1$} \\
\hline
\end{tabular}




\begin{tabular}{|c|c|c||c|c|}
\hline $\begin{array}{c}\text { Line for the } \\
\text { production of } \\
\text { alternative } \\
\text { fuel } \\
\text { R12 }\end{array}$ & $\begin{array}{c}\text { Waste from } \\
\text { polishing and } \\
\text { finishing, waste } \\
\text { from processed } \\
\text { textile fibers, } \\
\text { plastic packaging, } \\
\text { plastics and } \\
\text { textiles }\end{array}$ & 609.7 & $\begin{array}{c}\text { Combustible waste } \\
\text { (alternative fuel) } \\
(19 \text { 12 10) }\end{array}$ & 609.7 \\
\hline TOTAL & \multicolumn{2}{|c|}{$\mathbf{6 0 9 . 7}$} & & \\
\hline
\end{tabular}

In the case of biological waste treatment in the process of biostabilization, biodrying, composting and Kneer container composting, it would be unreliable to calculate the loss of mass from the above data, because some of the waste at the turn of the year, due to technological reasons, was transferred to various processes (D8, R3 or R12).

According to data obtained from the Plant, it should be assumed that the loss of mass in the biological treatment plant stands at approx. $19 \%$ - in the process of biodrying and in the range from $23 \%$ to $26 \%$ - in the biostabilization and composting process. In contrast, in the Kneer container composting system weight loss of approx. $30 \%$ was achieved.

\section{CONCLUSION}

The analyzed MBT plants are mainly supplied with mixed municipal waste, which constitutes from $78 \%$ to $96 \%$ of the input, alongside raw materials from selective municipal waste collection and various biodegradable fractions. The installations differ, among others, in the input to the mechanical part. Only about $4 \%$ of raw material waste collected selectively is sent to the Poświętne plant. It is a typical dry fraction of municipal waste (paper, plastics, metals, glass). The same applies to the installation in Kobierniki. Typical dry fractions from municipal waste are also found here (approx. 11\% of the input). However, in the third installation, the share of the raw material fraction is much larger - standing at nearly $20 \%$ - and apart from the typical dry fraction from municipal waste, largesize and construction waste is also accepted. The loss of mass occurs primarily during the biological treatment of waste, which is one of the objectives of this process.

Based on the analysis carried out one may conclude that, as a result of biochemical processes, weight loss in the range of about $15 \%$ to over $80 \%$ was obtained. The largest weight loss was recorded at the Plant in Poświętne. The level of $80 \%$ was exceeded when composting biodegradable waste collected selectively (from gardens and parks). This result, however, raises doubts, especially considering the 
short, approx. 5-week duration of the process. The outcome should be considered unlikely, especially as literature data indicate a loss of mass during biological processing ranging from $35 \%$ to $66 \%$ [Jędrczak 2008]. The discrepancy is probably the result of errors in the company's records and reporting or inaccurate mass measurements of individual waste fractions. As a correct value of the weight loss one should take the value obtained as a result of biological treatment of the undersieve fraction - standing at about $40 \%$, which is consistent with the literature reports. Significant weight loss (approx. 30\%) was also obtained in the Plant in Stary Las - as a result of container composting. In the case of composting in piles in containers with a maturing phase in the open and during biostabilization of the undersieve fraction, the result was slightly lower. The smallest weight loss (approx. 15\%) was observed as a result of the biological treatment of waste in the Plant in Kobierniki, although the biological part progresses there in similar conditions as in the installation in Poświętne. It should be underlined that the greater the weight loss, the less waste consequently goes to the landfill.

In plants in the towns of Kobierniki and Poświętne, the loss of waste mass has already been observed in the mechanical part (at a similar level in both installations). This fact may be caused by a high degree of moisture in the waste, and hence, a large amount of leachate on the sorting belt (including during the tearing of bags and perforation of bottles), which affects the balance of waste mass. It may be a consequence of mistakes made during selective collection, e.g. collecting sealed bottles with content. The technology supplier to ZUOK Stary Las does not show any loss of mass during mechanical processing in the sorting hall. It can be assumed that this is influenced by, among others, a slightly different character of the input - in terms of the share in raw material fractions as well as construction and large-size waste.

Further research should be carried out to assess the effectiveness of the MBT plant in terms of separating the fraction of raw materials.

\section{REFERENCES}

1. The balance of waste at Waste Management Plant in Kobierniki [Bilans odpadów z Zakładu Utylizacji Odpadów Komunalnych w Kobiernikach]; 2016.

2. The balance of waste at Waste Management Plant in Stary Las [Bilans odpadów z Zakładu Utylizacji Odpadów Komunalnych w Starym Lesie]; 2016

3. The balance of waste at Waste Management Plant in Poświętne [Bilans odpadów z Zakładu Zagospodarowania Odpadów w Poświętnem]; 2016.

4. Jędrczak, A 2008. Biological waste treatment [Biologiczne przetwarzanie odpadów komunalnych]. Warsaw: PWN Publisher. 
5. Kułak J 2017. Droga od MBP do RCR na podstawie doświadczeń RIPOK Adamki. X Jubileuszowa Konferencja Mechaniczno-biologiczne przetwarzanie odpadów. Koniec MBP? I co dalej?.

6. Marshall of Mazowieckie Voivodeship 2016, Decision No. 58/16/PZ.Z for the Waste Management Plant in Poświętne.

7. Marshall of Mazowieckie Voivodeship 2016, Decision No. 99/16/PZ.Z for the Waste Management Plant in Kobierniki.

8. Marshall of Pomorskie Voivodeship 2014, Decision No. DROŚSO.7222.46.2014.ES.

9. Marshall of Pomorskie Voivodeship 2014, Decision No. DROŚSO.7222.37.2016.Ał.

10.Mechanical-Biological-Treatment: A guide for decision makers processes; 2005

11.Resolution No. 88 of the Council of Ministers of 1 July 2016 on the National Waste Management Plan 2022, (Monitor Polski No. 88, item 784) (2016) [Uchwała Nr 88 Rady Ministrów z dnia 1 lipca 2016 r. w sprawie Krajowego planu gospodarki odpadami 2022; 2016. M.P. Nr 88, poz. 784].

12. Wiśniewska, M and Lelicińska-Serafin, K 2017. Biological waste treatment in Municipal Services Company in Płońsk based on the waste collected in Bodzanów commune [Biologiczne przetwarzanie odpadów komunalnych $\mathrm{w}$ Przedsiębiorstwie Gospodarki Komunalnej w Płońsku na przykładzie odpadów odebranych z obszaru gminy Bodzanów. In: Skoczko, I, Gładyczewska-Fiedorczuk, K, Weremijewicz, K, Witkowska, A (ed) Environmental Engineering with a Young Eye. Eco-energy [Inżynieria Środowiska - Młodym Okiem. Ekoenergetyka], Białystok: Publishing House of the Białystok University of Technology, p. 90-101

Editor received the manuscript: 29.05.2019 